Інноватика у вихованні. Випуск 12. 2020.

УДК 371.132

DOI: $\underline{10.35619 / \text { iiu.v1i12.282 }}$

Кошелева Наталя

кандидат педагогічних наук, доцент, доцент кафедри психології

Горлівського інституту іноземних мов ДВНЗ «Донбаський державний педагогічний університет»

м. Бахмут, Україна

ORCID:0000-0002-0380-3242, e-mail: cosheleva.natali@ukr.net

\title{
ФОРМУВАННЯ МЕТОДИЧНОЇ КОМПЕТЕНТНОСТІ МАЙБУТНІХ ВИКЛАДАЧІВ ПСИХОЛОГІЇ ЗАСОБАМИ ДИДАКТИЧНОГО ПРОЄКТУВАННЯ
}

\begin{abstract}
Анотація. У статті висвітлюється актуальна проблема формування методичної компетентності майбутніх викладачів психології, яка є важливою складовою їхньої професійно-педагогічної компетентності. Обгрунтовано необхідність запровадження практико-орієнтованого підходу до викладання дисципліни «Методика викладання психології у вищій школі». Запропоновано використання засобів дидактичного проєктування у процесі викладу практичної частини дисципліни 3 метою формування методичної компетентності майбутніх викладачів психології. Схарактеризовано структуру процесу розробки дидактичних проєктів 3 психологічних дисциплін. Сформульовано методичні пропозиції щодо змістового наповнення кожного 3 етапів дидактичного проєктування. У результаті виконання дидактичних проєктів майбутні викладачі психології отримують практичні навички виконання різноманітних видів методичної діяльності. Розроблені дидактичні проєкти мають бути реалізовані під час педагогічної (асистентської) практики, що підвищує ефективність іiі проходження магістрантами. Запропонований підхід переводить у практичну площину всі отримані ними теоретичні знання 3 методики викладання психології, забезпечує свідоме та обгрунтоване виконання методичної діяльності, усуває труднощі, пов'язані з підготовкою до проведення занять, i сприяє формуванню методичної компетентності майбутніх викладачів психології.
\end{abstract}

Ключові слова: професійно-педагогічна компетентність, методична компетентність, майбутні викладачі психології, дидактичне проєктування, методика викладання психології.

Постановка проблеми. Формування методичної компетентності майбутніх викладачів психології як важливої складової їхньої цілісної професійнопедагогічної компетентності є актуальним завданням підготовки магістрантів за спеціальністю 053 «Психологія». Професійна кваліфікація, яку вони отримують за результатами підготовки в ЗВО, передбачає як можливість професійної діяльності в якості практичних психологів, так і працевлаштування в заклади освіти різних рівнів на посаду викладача психології. Саме тому дуже важливими складовими навчальних планів магістратури $\epsilon$ дисципліна «Методика викладання психології у вищій школі» та педагогічна (асистентська) практика,

(C) Кошелева Н., 2020 
яка передбачає проведення магістрантами занять зі студентами-бакалаврами цієї спеціальності. Проте в реальній практиці ці складові підготовки магістрантів мають багато протиріч i складнощів. Традиційний підхід до вивчення дисципліни «Методика викладання психології у вищій школі» передбачає ознайомлення здобувачів освіти здебільшого 3 теоретичними поняттями дидактики, які студентам складно втілити в реальні заняття, і в них виникає дуже багато змістовних, методичних і організаційних труднощів та розчарувань у викладацькій діяльності. Окремо слід урахувати той чинник, що в магістратурі часто навчаються здобувачі, що вступали за принципом «перехресного вступу» $\mathrm{i}$ не мають базової педагогічної освіти. Тому надзвичайно важлива педагогічна (асистентська) практика часто відбувається формально, на низькому кваліфікаційному рівні і не дає жодної користі ні магістрантам, ні бакалаврампсихологам. Тому, необхідним $є$ інший, практико орієнтований підхід до реалізації зазначених складових підготовки магістрантів спеціальності 053 «Психологія». Ми пропонуємо реалізовувати такий підхід засобами дидактичного проєктування.

Аналіз останніх досліджень 3 проблеми. Практично всі дослідники, які вивчали проблеми формування професійної компетентності майбутніх педагогів (зокрема, С. Гончаренко, Р. Гуревич, О. Дубасенюк, I. Зимняя, I. Зязюн, Н. Кузьміна, М. Левківський, А. Маркова, Н. Ничкало, О. Овчарук, І. Підласий, О. Пометун, О. Савченко, О. Семеног, С. Сисоєва, В. Сластенін, А. Хуторський тощо), виокремлюють в їі структурі методичну складову, що «включає засвоєння педагогом нових методичних і педагогічних ідей, підходів до навчально-виховного процесу в сучасних особистісно-зорієнтованих, розвивальних, креативних технологіях, володіння різними методами, прийомами i формами організації навчання» (Ціпан, 2016, с. 177). Ця ж думка конкретизується в іншому дослідженні: «методична компетентність передбачає знання в галузі дидактики, методики навчання дисципліни, уміння логічно обгрунтовано конструювати навчальний процес для конкретної дидактичної ситуації 3 урахуванням психологічних механізмів засвоєння навчального матеріалу» (Ніколаєв та Рубаняк, 2016, с. 99). Дослідники акцентують увагу на тому, що «методична підготовка $є$ важливою та невід'ємною частиною професійної підготовки студента в умовах магістратури, а формування методичної компетентності обов'язкове для професійного становлення майбутніх викладачів, для здійснення подальшої трудової діяльності в університеті» (Рейдало, 2014, с. 267). Важливість формування методичної компетентності майбутніх викладачів підтверджують i новітні проєкти нормативних документів в освітній сфері - проєкти професійних стандартів учителя закладу загальної середньої освіти та викладача закладу вищої освіти (Міністерство освіти і науки України, 2020), які нещодавно пройшли громадське обговорення та очікують на затвердження.

Вивченню методичної компетентності педагога присвятили свої наукові розвідки В. Адольф, Н. Ерганова, В. Заболотний, Н. Глузман, А. Кузьминський, О. Лєбєдєва, С. Скворцова та ін. Низку досліджень присвячено проблемам формування методичної компетентності майбутніх вчителів фізики, математики, української мови та літератури, іноземної мови. Перспективним 3 точки зору запровадження НУШ $є$ дослідження методичної компетентності вчителів початкової школи (Гаєвець, 2012). Проте питання щодо формування методичної 
компетентності майбутніх викладачів психології поки не знайшло висвітлення в науковій літературі.

Теоретико-методологічні засади педагогічного (дидактичного) проєктування розробляли М. Алексєєв, О. Анісімов, Ю. Бабанський, В. Безрукова, В. Беспалько, Н. Брюханова, В. Загвязинський, О. Коваленко, М. Лазарєв, Б. Лихачов, М. Махмутов, Н. Тализіна, В. Якунін та інші науковці. Зазначимо, що найбільш практико-орієнтованим є науковий доробок О. Коваленко, втілений у розробленому нею авторському навчальному курсі «Методика професійного навчання», за допомогою якого студенти інженерно-педагогічних спеціальностей, що опановують цей курс, отримують усталені практичні навички розробки й реалізації дидактичних проєктів підготовки майбутніх фахівців робочих професій. Вважаємо, що при викладанні дисципліни «Методика викладання психології у вищій школі» для магістрантів спеціальності 053 «Психологія» варто вчити їх розробляти дидактичні проєкти 3 психологічних дисциплін, що викладаються на першому (бакалаврському) рівні вищої освіти. А під час педагогічної (асистентської) практики майбутні викладачі матимуть можливість реалізовувати розроблені проєкти навчання, контролювати рівень сформованих знань та вмінь студентів-бакалаврів, оцінювати їх відповідно до поставлених цілей та корегувати розроблені дидактичні проєкти, що має бути відображено у звіті про практику.

Мета статті - висвітлення специфіки використання засобів дидактичного проєктування для формування методичної компетентності майбутніх викладачів психології.

Виклад основного матеріалу дослідження. В якості вихідного положення зазначимо, що дидактичне проєктування $є$ процесом розробки проєктів фахової підготовки майбутніх фахівців та використовується 3 метою обгрунтованого та ефективного керування нею. Структура цього процесу, запропонована науковцями Української інженерно-педагогічної академії (Коваленко та ін., 2008 , с. 37), є такою: розробка проєкту навчання зі спеціальності (аналіз діяльності фахівця; розробка змісту професійної підготовки фахівця); розробка проєкту навчання 3 дисципліни чи теми (діагностика мети в навчанні; діагностика стану навчання; підготовка інформаційних матеріалів; добір навчальної літератури; розробка технологій навчання та контролю; планування навчального процесу).

Запропонований алгоритм може бути взятий за основу для розробки практичної частини викладання дисципліни «Методика викладання психології у вищій школі», але його зміст потребує суттєвого коригування відповідно до специфіки підготовки бакалаврів-психологів. Перший етап роботи магістрантів - це розробка проєкту навчання зі спеціальності, яка має здійснюватися у формі проєктної роботи всієї групи 3 індивідуальним розподілом завдань. Вона має починатися 3 визначення стратегічних цілей підготовки, тобто з аналізу професійної діяльності практичного психолога через вивчення освітніх стандартів, посадових інструкцій, кваліфікаційних характеристик, професіограм тощо. Як результат, має бути складена функціональна структура діяльності практичного психолога, яка в межах кожної виконуваної ним функції детально розкриває предмет, засоби, процес і продукт його діяльності. Оскільки процес діяльності має бути представлений у вигляді окремих дій, зважаючи на їхній зміст, формулюється перелік необхідних знань та вмінь, що надалі буде використаний як стратегічні цілі підготовки бакалаврів- 
Інноватика у вихованні. Випуск 12. 2020.

психологів і може бути відображений в освітньо-професійній програмі спеціальності.

Проєктування змісту навчання бакалаврів-психологів 3 психологічних дисциплін магістранти виконують 3 огляду на компетентності, визначені стандартом спеціальності, та спроєктовані стратегічні цілі, які конкретизують вимоги стандарту. На цій основі ними розробляється перелік вибіркових психологічних дисциплін підготовки бакалаврів-психологів. Отже, вони засвоюють ще один із видів діяльності науково-педагогічних працівників випускових кафедр - проєктування вибіркової частини навчального плану. Подальша практична робота магістрантів може бути пов'язана 3 розробкою робочої навчальної програми окремої вибіркової дисципліни, для чого їх необхідно ознайомити 3 відповідним алгоритмом і вимогами. Оскільки такий вид діяльності $\epsilon$ достатньо значним за обсягом, можна запропонувати магістрантам групову форму роботи над цим завданням.

Наступний етап проєктної роботи - це розробка проєкту навчання з окремої теми обраної дисципліни. Формою роботи мають бути індивідуальні проєкти. Найперше магістранти обирають навчальну тему 3 тієї вибіркової дисципліни, робочу програму якої вони розробляли на попередньому етапі, і конкретизують цілі ії викладання, зважаючи на раніше спроєктовані стратегічні цілі. При цьому пропонуємо опиратися на таксономію, розроблену В. П. Беспальком, яка передбачає формулювання оперативних цілей на чотирьох рівнях засвоєння навчального матеріалу (розпізнавання, репродуктивний, суб'єктивнопродуктивний, об’єктивно-продуктивний) (Беспалько, 1989, с. 55-56). Як наслідок формується перелік конкретних дій-еталонів бакалаврів-психологів 3 окремої навчальної теми, які вони повинні вміти виконувати після ії̈ засвоєння. Такий результат навчання легко вимірюється, контролюється й оцінюється, що й забезпечує надалі виконання вимог з організації контролю.

Далі магістрантам необхідно розробити систему контролю базових знань бакалаврів-психологів, які є необхідними для засвоєння навчального матеріалу обраної для розробки теми. 3 цією метою їм пропонується обрати $2-3$ базові теми $з$ цієї або інших дисциплін, визначити ключові для розуміння нової теми поняття, об'єкти, процеси та сформулювати контрольні питання (тести, завдання) для проведення вхідного контролю. При цьому від магістрантів вимагається розробити також і способи (методи, форми, засоби) актуалізації (формування) базових знань для усунення недоліків засвоєння базового матеріалу (повторення, нагадування, конспектування, пояснення, включення базового матеріалу у виклад нового під час лекції, складання глосаріїв, таблиць, виконання завдань та ін.). На цьому ж етапі необхідно проаналізувати наявні технічні та дидактичні засоби навчання та визначити можливість їх використання при опрацюванні теми.

Наступний етап: необхідно розробити інформаційні матеріали 3 теми: сформувати іiї логічну структуру, план, повний текст викладу теми та іï опорний конспект (для лекційних занять) або план проведення семінарського чи лабораторного заняття. 3 цією метою магістрантам пропонується дібрати та проаналізувати кілька сучасних джерел інформації з теми, визначити ключові питання, поняття та встановити логічні зв'язки між ними (у вигляді схеми), тобто побудувати модель навчального матеріалу. На цій основі необхідно сформувати план теми, який надалі буде розширюватися та конкретизуватися аж до повного конспекту викладача, в якому визначаються ключові аспекти для 
запису (опорний конспект) та додаткові - для усного пояснення чи обговорення. Таким чином конструюється зміст навчального матеріалу з теми.

Черговий етап передбачає проєктування технологій (методів, форм, засобів) навчання та контролю, що випливає 3 переліку визначених раніше оперативних цілей вивчення теми, сформульованих у вигляді переліку дій. Слід також звернути увагу магістрантів на те, що структура дії містить такі складові, як мотиваційна, орієнтовна, виконавча та контрольна (Гальперин, 2006), і що їм необхідно спроєктувати способи мотивації студентів, технології формування нових знань, технології формування та засвоєння діяльності i технології контролю сформованих дій. Зміст спроєктованих методів, форм і засобів навчання на кожному рівні засвоєння навчального матеріалу має бути детально розробленим і відповідати цілям рівня.

I нарешті останній етап - планування навчального процесу - має бути спроєктований відповідно до розподілу навчального часу, зазначеного у розробленій раніше робочій програмі дисципліни. На цьому етапі магістранти проєктують детальний зміст кожного заняття 3 теми, виходячи 3 усіх раніше виконаних методичних розробок та згідно зі структурою кожного типу заняття (лекційне, семінарське, лабораторне, консультаційне тощо). Зручно виконувати цю роботу у формі сценарію проведення заняття з таким складовими: структурні компоненти та етапи проведення заняття - дії викладача - дії студентів. Отже, майбутні викладачі психології отримують повноцінний до впровадження під час педагогічної (асистентської) практики дидактичний проєкт, який переводить у практичну площину всі отримані ними теоретичні знання, забезпечує свідоме та обгрунтоване виконання методичної діяльності, усуває труднощі, пов'язані 3 підготовкою до проведення занять, i сприяє формуванню методичної компетентності.

Висновки і перспективи подальших розвідок. Отже, вважаємо, що використання засобів дидактичного проєктування у процесі вивчення дисципліни «Методика викладання психології у вищій школі» та проходження педагогічної (асистентської) практики сприятиме формуванню методичної компетентності майбутніх викладачів психології та забезпечить більшу ефективність їхньої практичної підготовки до педагогічної діяльності. Подальші дослідження планується присвятити детальній розробці кожного 3 окреслених етапів та експериментальній перевірці сформульованих пропозицій.

\section{СПИСОК ВИКОРИСТАНИХ ДЖЕРЕЛ}

Ціпан, Т. (2016). Професійна компетентність сучасного вчителя. Інноватика у вихованні, 3. с. 174-181.

Ніколаєв, О. та Рубаняк, Л. (2016). Методична компетентність як одна із основних складових професіоналізму майбутнього вчителя. Збірник наукових праць Кам'янець-Подільського національного університету ім. Івана Огієнка. Серія: Педагогічна, 22, сс. 99-102.

Рейдало, В. (2014). Педагогічні умови формування методичної компетентності майбутніх викладачів української літератури. Наука і освіта, 5. c. 266-271.

Міністерство освіти і науки України, (2020). Професійний стандарт за професіями «Вчитель початкових класів закладу загальної середньої освіти», «Вчитель закладу загальної середньої освіти» (проект). Режим доступу: https://mon.gov.ua/ua/news/mon-proponuye-dlya-gromadskogo-obgovorennya- 
proyekt-profstandartu-za-profesiyami-vchitel-pochatkovih-klasiv-zzso-vchitel-zzso [дата звернення 20 липня 2020].

Міністерство освіти і науки України, (2020). Професійний стандарт на посади «Асистент», «Викладач», «Стариий викладач», "Доцент», «Професор» (проект). Режим доступу: https://mon.gov.ua/ua/news/mon-proponuye-dlyagromadskogo-obgovorennya-proyekt-profstandartu-na-posadi-asistent-vikladachstarshij-vikladach-docent-profesor [дата звернення 20 липня 2020].

Гаєвець, Я. (2012). Методична компетентність як мета та результат підготовки вчителя початкових класів. Наука і освіта, 8. с. 38-42.

Коваленко, О., Брюханова, Н., Корольова, Н. та Шматков, С. (2008). Методика професійного навчання. Харків: ВПП «Контраст». 488 с.

Беспалько, В. (1989). Слагаемые педагогической технологии. Москва: Педагогика. 192 с.

Гальперин, Я. (2006). Введение в психологию. Москва: КДУ. 327 с.

\section{REFERENCES}

Tsipan, T. (2016). Profesiina kompetentnist suchasnoho vchytelia [Professional competence of a modern teacher]. Innovatyka $u$ vykhovanni, 3. ss. 174-181.[in Ukrainian]

Nikolaiev, O. ta Rubaniak, L. (2016). Metodychna kompetentnist yak odna iz osnovnykh skladovykh profesionalizmu maibutnoho vchytelia [Methodological competence as one of the main components of the professionalism of a future teacher]. Zbirnyk naukovykh prats Kamianets-Podilskoho natsionalnoho universytetu im. Ivana Ohiienka. Seriia: Pedahohichna, 22, ss. 99-102. [in Ukrainian]

Reidalo, V. (2014). Pedahohichni umovy formuvannia metodychnoi kompetentnosti maibutnikh vykladachiv ukrainskoi literatury [Pedagogical conditions for the formation of methodological competence of future Ukrainian literature teachers]. Nauka i osvita, 5. ss. 266-271. [in Ukrainian]

Ministerstvo osvity i nauky Ukrainy, (2020). Profesiinyi standart za profesiiamy "Vchytel pochatkovykh klasiv zakladu zahalnoi serednoi osvity", "Vchytel zakladu zahalnoi serednoi osvity" (proekt) [Professional standard for the profession "Primary school teacher of a general secondary education institution", "Teacher of a general secondary education institution" (draft)]. URL: https://mon.gov.ua/ua/news/monproponuye-dlya-gromadskogo-obgovorennya-proyekt-profstandartu-za-profesiyamivchitel-pochatkovih-klasiv-zzso-vchitel-zzso [Data zvernennia 20 lypnia 2020].[in Ukrainian]

Ministerstvo osvity i nauky Ukrainy, (2020). Profesiinyi standart na posady "Asystent», "Vykladach”, "Starshyi vykladach”, "Dotsent”,"Profesor" (proekt) [Professional standard for the positions "Assistant", "Teacher", "Senior Teacher", "Associate Professor", "Professor" (draft)]. URL: https://mon.gov.ua/ua/news/monproponuye-dlya-gromadskogo-obgovorennya-proyekt-profstandartu-na-posadiasistent-vikladach-starshij-vikladach-docent-profesor [Data zvernennia 20 lypnia 2020]. [in Ukrainian]

Haievets, Ya. (2012). Metodychna kompetentnist yak meta ta rezultat pidhotovky vchytelia pochatkovykh klasiv [Methodological competence as the goal and result of training a primary school teacher]. Nauka i osvita, 8. ss. 38-42. [in Ukrainian]

Kovalenko, O., Briukhanova, N., Korolova, N. ta Shmatkov, Ye. (2008). Metodyka profesiinoho navchannia [Professional education methodology]. Kharkiv: VPP “Kontrast”. 488 s. [in Ukrainian] 
Bespalko. V. (1989). Slagayemyye pedagogicheskoy tekhnologii [Components of pedagogical technology]. Moskva: Pedagogika. 192 s. [in Russian]

Galperin. Ya. (2006). Vvedeniye v psikhologiyu [Introduction to Psychology]. Moskva: KDU. 327 s. [in Russian]

\title{
METHODOLOGICAL COMPETENCE FORMATION OF FUTURE PSYCHOLOGY TEACHERS BY MEANS OF DIDACTIC DESIGN
}

\author{
Kosheleva Natalia \\ Candidate of Pedagogical Sciences (Ph. D.), \\ Associate Professor at the Department of Psychology \\ Horlivka Institute for Foreign Languages of the \\ State Higher Educational Establishment "Donbas State Pedagogical University", \\ Bakhmut, Ukraine \\ ORCID:0000-0002-0380-3242, \\ e-mail: cosheleva.natali@ukr.net
}

\begin{abstract}
The article highlights the actual problem of formation the methodological competence of future psychology teachers, which is an important component of their professional and pedagogical competence. The approaches of scientists about the essence and problems of the formation of the methodological competence of future teachers were analyzed. The necessity of introducing a practiceoriented approach to teaching the discipline "Methods of teaching psychology in higher education" is substantiated. It is proposed to use didactic design tools in the process of presenting the practical part of this discipline in order to form the methodological competence of future teachers of psychology. The process structure of developing didactic projects of psychological disciplines is described. The process includes two main components: developing a training project for a specialty and developing a training project for a discipline or topic. Each component contains a number of stages for the implementation of didactic projects. The main stages are: analysis of the specialist's activities; development of the content of professional training of a specialist; diagnostics of the goal in training; diagnostics of the state of learning; preparation of information materials; selection of educational literature; development of training and control technologies; planning the educational process. Methodological proposals are formulated for the content of each of the stages of didactic design. As a result of the implementation of didactic projects, future psychology teachers gain practical skills in performing various types of methodological activities. The developed didactic projects should be implemented during pedagogical (assistant) practice, increasing the efficiency of its passage by undergraduates. The proposed approach translates into a practical plane all the theoretical knowledge they have acquired on the methodology of teaching psychology, ensures the conscious and justified implementation of methodological activities, eliminates the difficulties associated with preparing for classes and contributes to the formation of the methodological competence of future psychology teachers.

Key words: professional and pedagogical competence, methodological competence, future psychology teachers, didactic design, psychology teaching methodology.
\end{abstract}

Стаття надійшла до редакиї 10. 09. 2020 р. 